\title{
The Global boundary Stratotype Section and Point (GSSP) of the Ladinian Stage (Middle Triassic) at Bagolino (Southern Alps, Northern Italy) and its implications for the Triassic time scale
}

\author{
1 Departement Erdwissenschaften, ETH-Zentrum, CH-8092 Zürich, Switzerland. \\ 2 Paläontologisches Institut, Universität Zürich, CH-8006 Zürich, Switzerland. \\ 3 Dipartimento di Scienze della Terra, Università di Milano, Via Mangiagalli 34, I-20133 Milano, Italy. \\ 4 Berkeley Geochronology Center, 2455 Ridge Road, Berkeley, CA 94709, USA.
}

The Global boundary Stratotype Section and Point (GSSP) for the base of the Ladinian Stage (Middle Triassic) is defined in the Caffaro river bed $\left(45^{\circ} 49^{\prime} 09.5^{\prime \prime} \mathrm{N}\right.$, $\left.10^{\circ} 28^{\prime} 15.5^{\prime \prime} \mathrm{E}\right)$, south of the village of Bagolino (Province of Brescia, northern Italy), at the base of a 15-20-cm-thick limestone bed overlying a distinct groove ("Chiesense groove") of limestone nodules in a shaly matrix, located about $5 \mathrm{~m}$ above the base of the Buchenstein Formation. The lower surface of the thick limestone bed has the lowest occurrence of the ammonoid Eoprotrachyceras curionii (base of the E. curionii Zone; onset of the Trachyceratidae ammonoid family). Secondary global markers in the uppermost Anisian include the lowest occurrence of conodont Neogondolella praehungarica and a brief normal-polarity magnetic zone recognized in closely correlated sections including the principal auxiliary section at Seceda in the Dolomites. The GSSP-level is bracketed by U-Pb single zircon age data from volcaniclastic horizons, indicating a boundary age of ca $241 \mathrm{Ma}$.

\section{Introduction}

In this article the Global boundary Stratotype Section and Point (GSSP) for the base of the Ladinian Stage is presented in accordance with its ratification in spring 2005 by the IUGS Executive Committee following its approval by the International Commission on Stratigraphy (13 votes Yes [93\%], 1 abstention, 3 votes not received) and a previous favourable vote by the Triassic Subcommission on the modified version of the proposal by Brack et al. (2003). This is the first ratified GSSP within the Triassic System and its location is based on results of intense multidisciplinary research on the Anisian/Ladinian boundary interval carried out mainly over the last two decades.

After a brief overview of the historical and regional geological context information will be given on the criteria for selecting the principal stratigraphic markers and the location of the GSSP. Finally, the numeric age of the Ladinian GSSP and the significance for the Triassic time scale are briefly discussed.

\section{Historical context of the Ladinian Stage}

The first formal recognition of a stratigraphic interval comprising what is now called Ladinian orginates from the subdivisions of the Triassic System proposed by E.v. Mojsisovics. Ammonoids served as the main biostratigraphic tool for these divisions. By 1874 and with later modifications (e.g., 1882), Mojsisovics used the name "Norian" for a stratigraphic interval including, at its base, the South Alpine Buchenstein Beds and siliceous limestones of Bakony (Hungary). Because Mojsisovics erroneously equated this interval with parts of the ammonoidrich Hallstatt-limestones, he used the term "Norian" as the stage name, which refers to the Norian Alps around Hallstatt near Salzburg (Austria). Later, these Hallstatt-ammonoids were found to be much younger. Bittner (1892) therefore proposed the term "ladinisch" (Ladinian, after the "Ladini"-people of the Dolomites area) as a new label for the stratigraphic interval comprising the South Alpine Buchenstein and Wengen Beds. Although not adopted by Mojsisovics et al. (1895), the Ladinian subsequently became the generally accepted stage name (e.g., Arthaber, 1906; for additional information and discussions of the history of the Ladinian see Brack \& Rieber, 1994 and Kozur, 1995). Only little progress was made in the following decades on the (bio)stratigraphy of the Buchenstein and equivalent intervals.

In Mojsisovics' time, knowledge of ammonoid successions in the Anisian/Ladinian boundary interval was fragmentary and stratigraphic correlations rather speculative. For instance, the South Alpine Buchenstein Beds and siliceous limestones in Bakony were considered age equivalents and both attributed to the "T. reitzi" Zone. However, unambiguous evidence from recent biostratigraphic research on ammonoids, conodonts and radiolaria shows that the main ammonoid bearing interval of Mojsisovics' "yellow siliceous limestones of Bakony" (now called the "Vàszoly Fm.") partly predates and overlaps in age with only the lowermost parts of the South Alpine Buchenstein Formation.

Starting in the 1960s numerous classical localities for Middle Triassic fossils of the Western Tethys were restudied and new schemes of ammonoid zones were sketched, with the Anisian/Ladinian boundary being placed at different stratigraphic positions. North American geologists meanwhile preferred to define their own stage boundary at yet another stratigraphic level (see e.g., schemes in Zapfe, 1983; Tozer, 1984).

For a modern definition of the base of the Ladinian Stage, the perplexities associated with original concepts and historical usage of the Anisian/Ladinian boundary provide no useful basis for the positioning of the GSSP. However, the lower part of the South Alpine Buchenstein Formation is an adequate interval for the Ladinian GSSP because Bittner (1892) explicitly designated this stratigraphic unit as the oldest one of the stage. 


\section{Selection of boundary section and level}

Over the last two decades the successions of ammonoids in Anisian/Ladinian boundary intervals have been established with unprecedented precision in predominantly pelagic successions in the Western Tethys (mainly Southern Alps, Greece and Hungary; e.g., Rieber, 1973; Krystyn \& Mariolakos, 1975; Brack \& Rieber, 1993; Vörös, 1998) and North America (Nevada; Silberling \& Nichols, 1982). Similar progress was made in research on conodont successions (e.g., Krystyn, 1983; Kovács, 1994; Bucher \& Orchard, 1995; Gallet et al., 1998; Brack \& Nicora, 1998; Muttoni et al., 2004b) documenting that the resolution power of conodonts is somewhat lower but their occurrences are likely more widespread. Knowledge on intercalibrated distributions of other fossil groups (Daonella, radiolaria, dasycladaceans, palynomorphs) is still somewhat fragmentary. Magnetostratigraphic data (Muttoni et al., 2004b) and results from highresolution radio-isotopic dating (Mundil et al., 1996b,c, 2003; Pálfy et al., 2003) are available from marine successions in the Western Tethys.

Based on these results at least five different stratigraphic positions have been discussed as potential candidates for the Anisian/ Ladinian boundary. A boundary definition based mainly on ammonoids but in combination with conodonts has proved to have the highest potential for long-distance correlations. Of the noncondensed sections with adequate records of these fossil groups two candidates (Bagolino, Italy; Felsöörs, Hungary) soon emerged as viable alternatives, both being integrated with results from magnetostratigraphy and radio-isotopic dating. In the two sections, eventually, three different stratigraphic levels were formally proposed and considered as GSSP-candidates. In ascending stratigraphic order these are:

1 ) the base of the R. reitzi (Sub)Zone with a repositioned base (with

respect to earlier Hungarian proposals), i.e. at layer 105 in the Felsöörs section (Vörös et al., 2003a);

2) the base of the avisianum Subzone at Site $C$ and the $57.71 \mathrm{~m}$-level of the Bagolino reference column (Mietto et al., 2003b); and

3 ) the base of the E. curionii Zone at the $63.25 \mathrm{~m}$-level of the Bagolino reference column at site B (Brack et al., 2003).

The third option was eventually preferred because of its potential for long-distance correlations on the basis of ammonoids and conodonts and because the GSSP-location lies within an extended stratigraphic record which can be tied to sections with a reproducible succession of magnetic reversals. Moreover, the Southern Alps have long been considered as the type area for the Ladinian.

\section{The Ladinian GSSP at Bagolino and supplementary stratigraphic information}

\section{Geological setting of the Middle Triassic succession at Bagolino}

The Middle Triassic succession at Bagolino (Eastern Lombardy, northern Italy) is part of a thick sediment prism comprising Lower to Upper Triassic strata, which are turned upright in front of an uplifted portion of the Brescian Prealps. The latter area is situated to the north of a bounding fault (Val Trompia Line) and consists of pre-Permian metamorphic basement covered by Lower Permian to Triassic rocks. Alpine deformation of the Middle to Upper Triassic rocks south of the Val Trompia Line was the result of south-directed tectonic transport of basement and cover which occurred in two phases, prior to and after the emplacement of the Eocene-Oligocene Adamello intrusives.

Pelagic successions of Middle Triassic age are also visible to the south-west of Bagolino (Figure 1), including the classical locality at Dosso Alto and important complementary sections at Pèrtica, Brozzo and Marcheno. Further north, Middle Triassic pelagic sediments occur along the southern margin of the Adamello intrusions. This area hosts important fossiliferous sections in Giudicarie

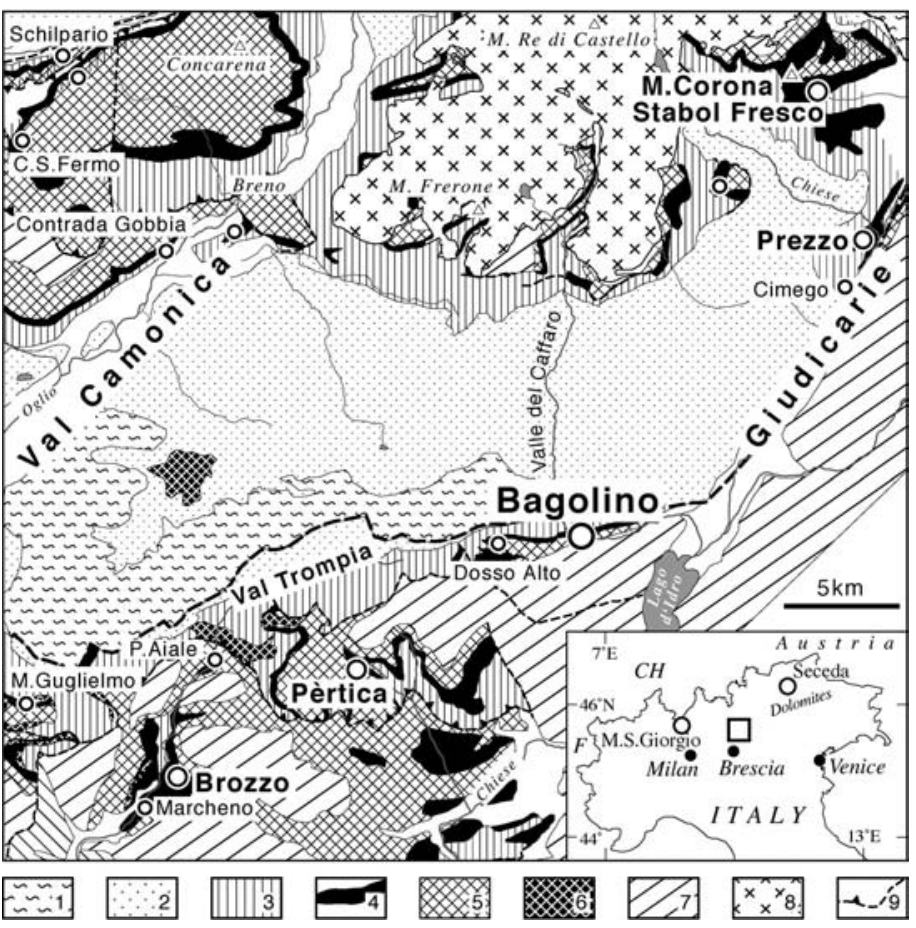

Figure 1 Geological sketch map of the area with classical localities of Middle Triassic stratigraphy in eastern Lombardy and Giudicarie (Trentino). 1-Pre-Permian basement; 2-Permian to Lower Triassic including lowermost Anisian units; 3-Mainly Lower/Middle Anisian units (Angolo Lst.; Dosso dei MortiCamorelli Lst.); 4-Upper Anisian-Ladinian pelagic successions (Prezzo Lst., Buchenstein and Wengen Fms.); 5-Ladinian/ Carnian platform carbonates and age-equivalent intra platform deposits (Pratotondo Lst., Lozio Shales); 6-Ladinian-Carnian shallow intrusive rocks; 7-Norian-Rhaetian shallow water carbonates and basinal equivalents; 8-Tertiary Adamello plutonics; 9-major tectonic lines (faults and thrusts).

(Prezzo, at the eastern termination of Val di Daone; Monte Corona Stabol Fresco) and in Val Camonica (e.g., Contrada Gobbia).

At Bagolino, the pelagic succession consists, in stratigraphic order, of the Prezzo Limestone, the Buchenstein Formation and the

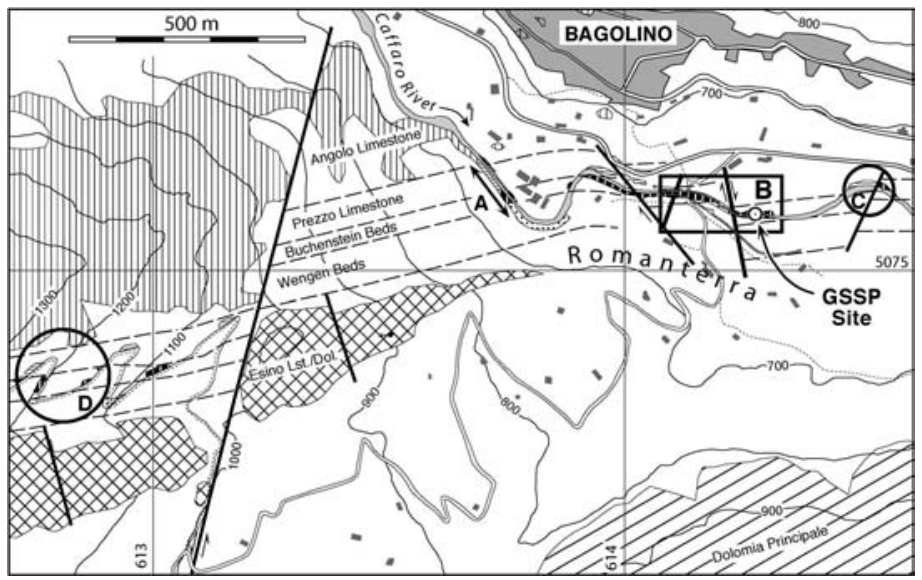

Figure 2 Geological sketch map of the vertical to slightly overturned Middle Triassic succession in the surroundings of Bagolino. The main sites (A-D) with exposures of the Anisian/ Ladinian boundary interval are indicated. The stratigraphic ranges of the intervals exposed at each site are shown in Figure 3. A continuous succession ranging from the uppermost Angolo Limestone to the Wengen Formation is exposed at Site A. The frame at Site $B$ outlines the area of a detailed map of this outcrop as illustrated in fig. 4 of Brack \& Rieber (1986). Coordinates of GSSP-Site: Long./Lat. N 4549'09.5’', E 10²8'15.5’'. 


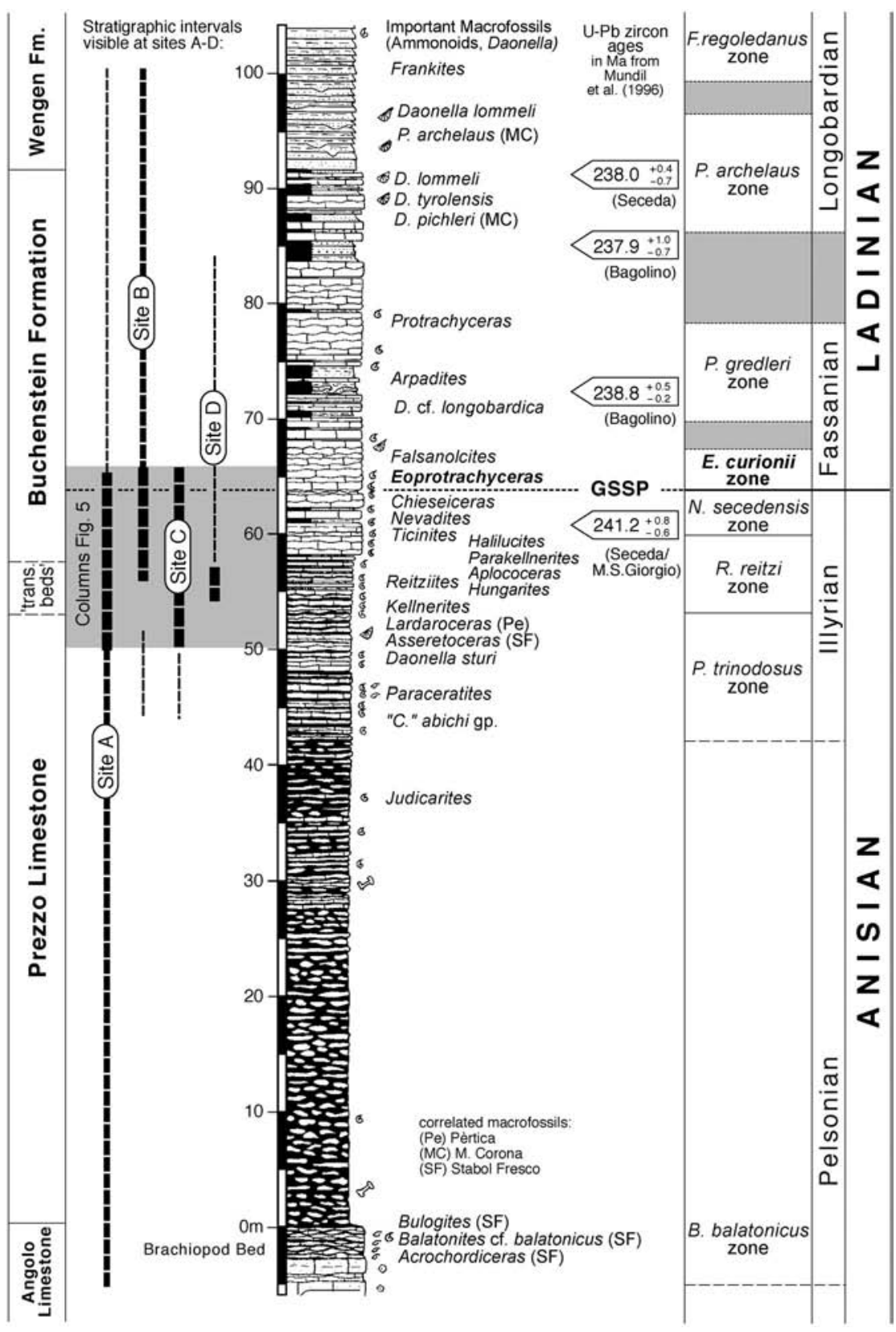

Figure 3 Summary log of the Middle Triassic pelagic succession at Romanterra (Bagolino). The stratigraphic intervals exposed at Sites $A-D$ as well as the main macrofossil horizons and the scheme of ammonoid zones are indicated. Radioisotopic age data are weighted mean $U$-Pb-ages (uncertainties at $95 \%$ confidence level) on single grain zircon from volcaniclastic layers at Bagolino and Seceda (from Mundil et al., 1996b). Range of the Pelsonian substage after Vörös et al. (2003b). Note that the Fassanian substage suggested here comprises the E. curionii and P. gredleri Zones. Although the $\mathbf{P}$. gredleri Zone still awaits a proper definition its inclusion into the Fassanian more closely matches the original concept for these substages (Mojsisovics et al., 1895), with the Fassanian largely corresponding to the Buchenstein Fm. (and Marmolada Lst.) and the Longobardian corresponding to the Wengen Formation.

Wengen Formation. These strata are well exposed at different places in the Caffaro river bed at Romanterra (Figures 2-3) as well as in outcrops on the southern slopes of M. Pizza (Site D). Additional exposures of the same strata are accessible along the Rio Ricomassimo creek around $3 \mathrm{~km}$ east-northeast of Romanterra. Prior to recent research (Brack \& Rieber, 1986, 1993; Brack et al, 1995; Mietto et al., 2003a) the presence of the Buchenstein Formation south of the village of Bagolino (Site B) was indicated by Bittner (1881). Mariani (1906) documented the first few ammonoids from this area.

\section{The pelagic succession of Bagolino}

The stratigraphic succession exposed at Romanterra (Bagolino; Figures 2-3) starts in the uppermost Angolo Limestone with a distinct brachiopod lumachella at its top. The pelagic Prezzo Limestone consists of limestone-shale alternations with nodular to wavy bedding in the lower part and more regular and thicker bedding in the upper part. In an interval transitional to the Buchenstein Formation, the first significant volcaniclastic layers are interbedded with increasingly siliceous limestones and shales. The reduction of the clay content at the base of the Buchenstein Formation suggests a decrease of the sedimentation rate from moderately high values in the Prezzo Limestone to low values in the Buchenstein Formation. The Buchenstein Formation consists of siliceous pelagic nodular limestones and volcaniclastic layers, up to a few decimetres thick, that can be traced laterally on a regional scale. On the basis of radio-isotopic age constraints, the average sedimentation rates in the equivalent (non-decompacted) siliceous pelagic nodular limestone of the Buchenstein Formation in the western and central Dolomites are estimated to be in the order of $10 \mathrm{~m} / \mathrm{m}$.y. (Brack \& Muttoni, 2000). However, the thickness of corresponding intervals of the Buchenstein Formation in sections in eastern Lombardy (including Bagolino) and Giudicarie is reduced by $40-50 \%$ and the rates of sedimentation are accordingly lower. The layers with predominantly airborne volcaniclastic material obviously represent short-lived deposition on the scale of duration of volcanic eruptions. A marked change in sedimentation is observed at the top of the Buchenstein Formation with the abrupt switch to the siliciclastic Wengen Formation. At Bagolino this interval predominantly consists of storm deposits and, again, displays rapid sediment accumulation. In spite of these highly variable rates of sediment accumulation no signs of stratigraphic gaps have been detected so far in the $>100 \mathrm{~m}$ thick succession of Middle Triassic pelagic sediments at Bagolino.

In this stratigraphic succession the Anisian/ Ladinian boundary interval comprises the "transitional beds" and the lower part of the Buchenstein Formation and is best exposed at Sites A to C. At the eastern end of Site B the fully exposed and steeply dipping strata from the $57 \mathrm{~m}$-level upward can be traced over several tens of meters along strike (Figure 4; for a detailed map of this outcrop see fig. 4 in Brack \& Rieber, 1986).

\section{Stratigraphic extent and completeness of the Bagolino section}

The pelagic succession at Bagolino (Figure 3) represents a time interval between Middle/Late Anisian and Late Ladinian. Ammonoid faunas of the B. balatonicus Zone are known from Giudicarie (e.g., Balini et al., 1993; Brack et al., 1999) from a stratigraphic level corresponding to the Brachiopod Bed at Bagolino. The Prezzo Limestone at Bagolino bears determinable ammonoids from the Judicarites-horizons upwards. Nearby sections of Prezzo Limestone (e.g., Stabol Fresco, Contrada Gobbia; see Balini et al., 1993; Balini, 1998) host one of the richest ammonoid faunas reported so far for the P.trinodosus Zone in Western Tethys. At Bagolino the ammonoid horizons (Figure 5) are particularly frequent in the lower Buchenstein Formation and in the underlying beds transitional from the Prezzo Limestone (R. reitzi, N. secedensis and E.curionii Zones). 


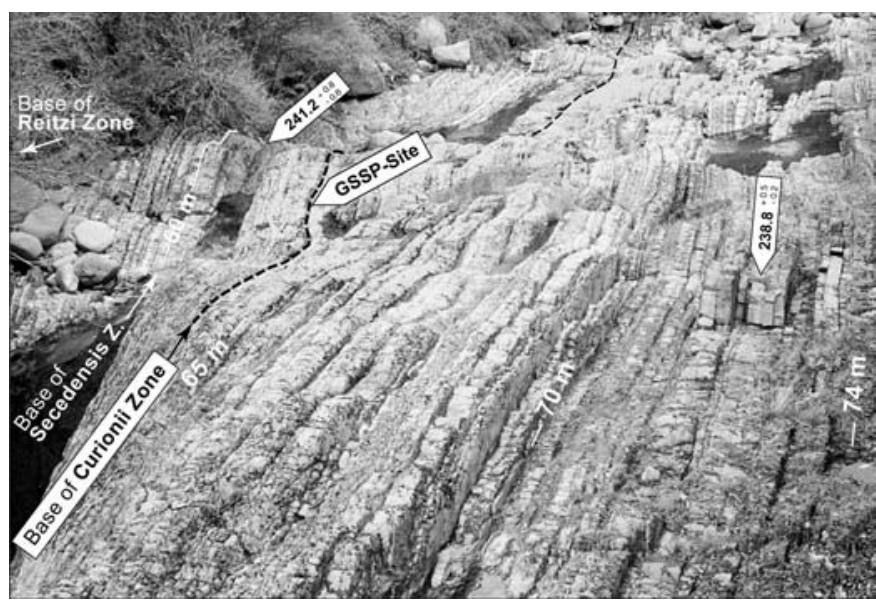

Figure 4 View of the spectacular outcrop of Buchenstein Formation at Site B (eastern end; = GSSP-Site) with a continuous exposure of strata between $\mathrm{R}$. reitzi Zone and $\mathrm{P}$. archelaus Zone (base of Wengen Fm.). Stratigraphic polarity is from left (old) to right (young).
Ammonoids and Daonella also occur in the upper Buchenstein and Wengen Fms., with representatives of Frankites ( $F$. regoledanus Zone) being the youngest ammonoids known to date.

Comparable fossil bearing sections elsewhere in the Southern Alps are usually either condensed (e.g., Clap di Val: see Mietto \& Manfrin, 1995, Rieber \& Brack, 2004), show fewer ammonoid bearing horizons (e.g., Seceda, Val Gola) or have a limited stratigraphic range (e.g., M.S. Giorgio) and/or a discontinuous fossil record in platform carbonates (e.g., storm-layers in the plaform-interior beds at Latemar; e.g. Mundil et al., 2003; Manfrin et al., 2005). The strongly expanded but punctuated ammonoid record from Latemar corresponds to only a narrow stratigraphic interval of the Buchenstein Fm. (mainly upper part of $R$. reitzi Zone to $N$. secedensis Zone). However, the resolution of clearly age diagnostic ammonoid taxa at Latemar does as yet not approach that of the corresponding basinal record. Contrary to the conclusions of Manfrin et al. (2005), the analysis of large and similar ammonoid faunas in Hungary suggests that environmental control on ammonoid distributions in peri-platform and basinal settings was indeed significant (Vörös, 2002).

Because of the apparent absence of small ammonoid taxa and juveniles along with observed dissolution features on ammonoid specimens Preto et al. (2005) seem to question the suitability of the nodular limestone facies ("Knollenkalke" of the Buchenstein Fm.) as a carrier of an unbiased ammonoid record. In the view of these authors the shells of small ammonoids may have been removed at the sediment-water interface through widespread aragonite dissolution related to the inflow of cool deep ocean waters onto the floors of the South Alpine Buchenstein basins. The following observations suggest that the scenario proposed by Preto et al. (2005) may not be plausible: i) During Anisian-Ladinian times, the realm of the Southern Alps was located at the western termination of Paleotethys at a paleolatitude of around $18^{\circ} \mathrm{N}$ (e.g., Brack et al., 1999). This "remote" position and the reduced size and irregular geometry of the Buchenstein basins appear rather unfavourable for ocean-scale circulation patterns reaching the South Alpine domain; ii) In the nodular limestone facies of the Buchenstein-type numerous ammonoid specimens show signs for dissolution but the same also holds true for the sediment fills and the calcareous rock matrix surrounding the ammonoids. Post-depositional diagenetic alteration and/or compaction are thus more likely causes for carbonate dissolution. Maurer \& Schlager (2003) convincingly showed how primary sedimentation patterns have been obliterated by bioturbation and the postdepositional redistribution of carbonate. Although the ammonoid record may have suffered from
Figure 5 Detailed stratigraphic logs with distribution of ammonoids in intervals around the Anisian/Ladinian boundary at sites A-D. Specific volcaniclastic marker beds used for bed-by-bed correlation are indicated and labelled. The GSSP is at Site B (eastern end), i.e. at the base of the E. curionii Zone corresponding to the base of a 15-20-cm-thick limestone bed overlying a recessive weathered interval with limestone nodules in a shaly matrix ("Chiesense groove"). 

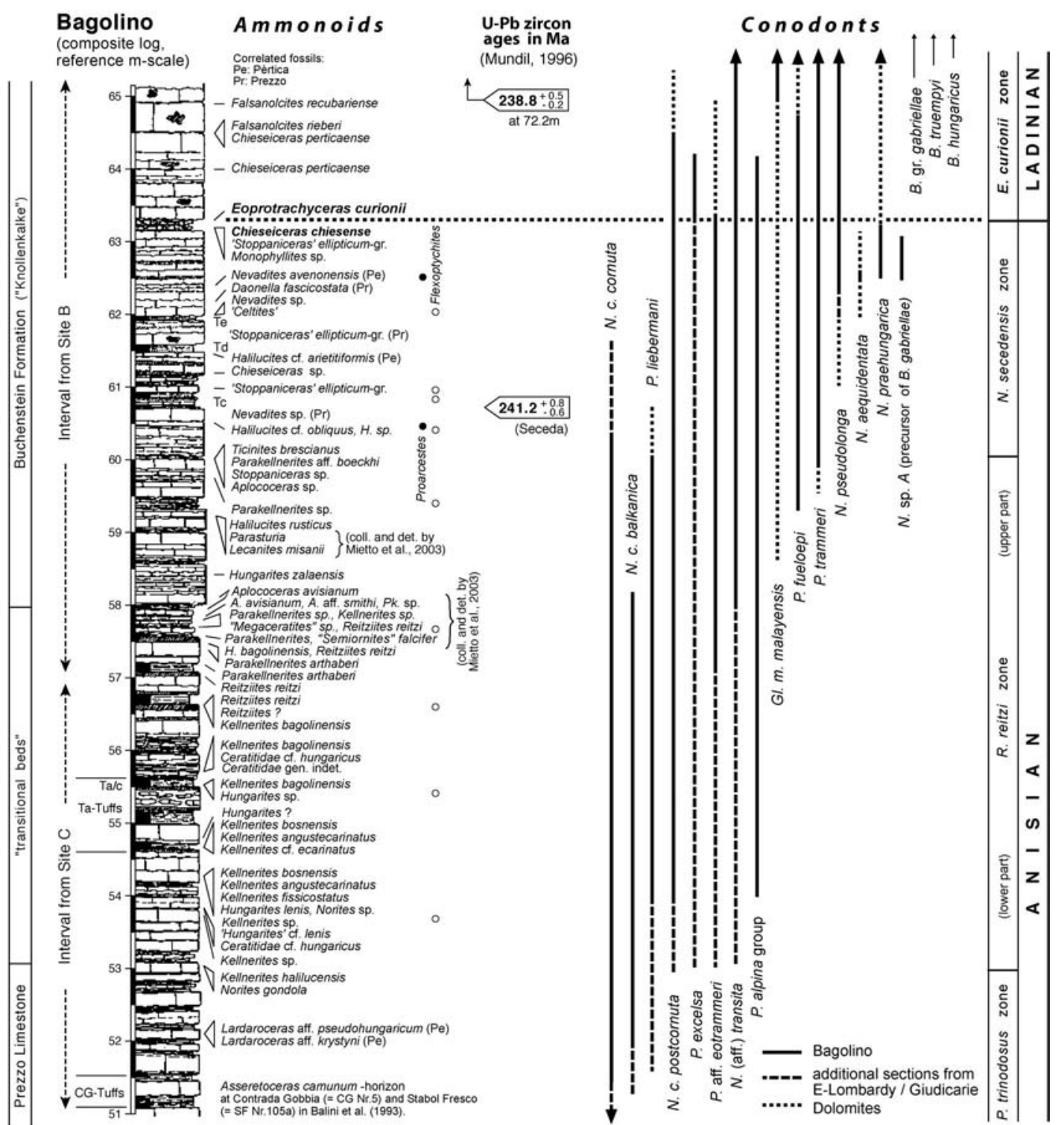

and its coordinates are 614.276/ 5075.118 (UTMgrid) and Long./Lat. $45^{\circ} 49^{\prime}$ $09.5^{\prime}{ }^{\prime} \mathrm{N}, \quad 10^{\circ} 28^{\prime} 15.5^{\prime}{ }^{\prime} \mathrm{E}$ respectively. Parts of the outcrops at Site B may be temporarily submerged during high river waters in spring or after heavy showers. The other sites with the exposed GSSP-level are easily accessible with restrictions only during severe winter conditions.

The GSSP-level at Bagolino is defined in the lower part of the Buchenstein Formation at the base of a 15-20-cm-thick limestone bed overlying a distinct groove ("Chiesense groove") of limestone nodules in a shaly matrix, located about $5 \mathrm{~m}$ above the base of the "Knollenkalke" (nodular limestones) of the Buchenstein Formation (Figures 5 and 6). The nodular limestone interval known as the "Chiesense groove" bears ammonoids such as Chieseiceras chiesense and 'Stoppaniceras' (ellipticumgroup). The lowest occurrence of Eoprotrachyceras curionii in the GSSP is documented on the lower surface of the overlying thick limestone bed. Macrofossils were found at this level at all sites described here for the Bagolino area (Figures 2,3,5). Because of the particularly vast exposure, the eastern end of Site B (Figure 4) is designated as the principal outcrop/section for the GSSP. the average sample spacing is around $18 \mathrm{~cm}$ above and $50 \mathrm{~cm}$ below the $58 \mathrm{~m}$-level respectively). Also shown are correlated complementary conodont data from additional sections in eastern Lombardy (Brozzo, Pèrtica) and Giudicarie (Stabol Fresco) as well as in the Dolomites (Muttoni et al., 2004b).

processes leading to the formation of nodular limestone, there is as yet no evidence that this has resulted in stratigraphic condensation and/or distinct hiatuses in the ammonoid record.

The Bagolino section is thus arguably the most extensive, uncondensed, and macrofossil-bearing Middle Triassic succession known so far in and beyond the Southern Alps, and it is the only place in the realm of the Western Tethys where, in a single section, all levels discussed as potential Anisian/Ladinian boundary have been identified on the basis of ammonoids!

\section{Location and definition of the GSSP}

The GSSP for the base of the Ladinian Stage at Bagolino (Province of Brescia, Northern Italy) is located in the eastern Lombardian Alps, and more precisely, in Valle del Caffaro between Val Camonica and Valli Giudicarie (Figure 1). The Anisian/Ladinian boundary succession is well exposed at three sites in the bed of the river Caffaro near the Romanterra bridge, south of the village of Bagolino (Sites A-C; see Figure 2). The GSSP-Site is situated close to the eastern end of Site B, i.e. approximately $150 \mathrm{~m}$ ESE of the bridge

\section{Auxiliary section and additional stratigraphic information}

Complementary stratigraphic results from relevant South Alpine Anisian/Ladinian boundary sections are shown in Figure 7. Of these Seceda is designated as the principal auxiliary section for the Ladinian GSSP, mainly because it adds well-correlated magnetostratigraphy, (radio)isotope and complementary conodont data to the information from Bagolino. Much of this information was acquired through multidisciplinary research of the Seceda core (Brack et al., 2000) which so far resulted in a sedimentological characterisation of Buchenstein lithologies (Maurer \& Schlager, 2003) as well as in detailed findings from studies using magnetostratigraphy and conodont biostratigraphy (Muttoni et al., 2004b). However, the stratigraphic range and number of macrofossil levels known from Seceda is clearly inferior to the range and resolution of the fossil record in the GSSP-section at Bagolino. 


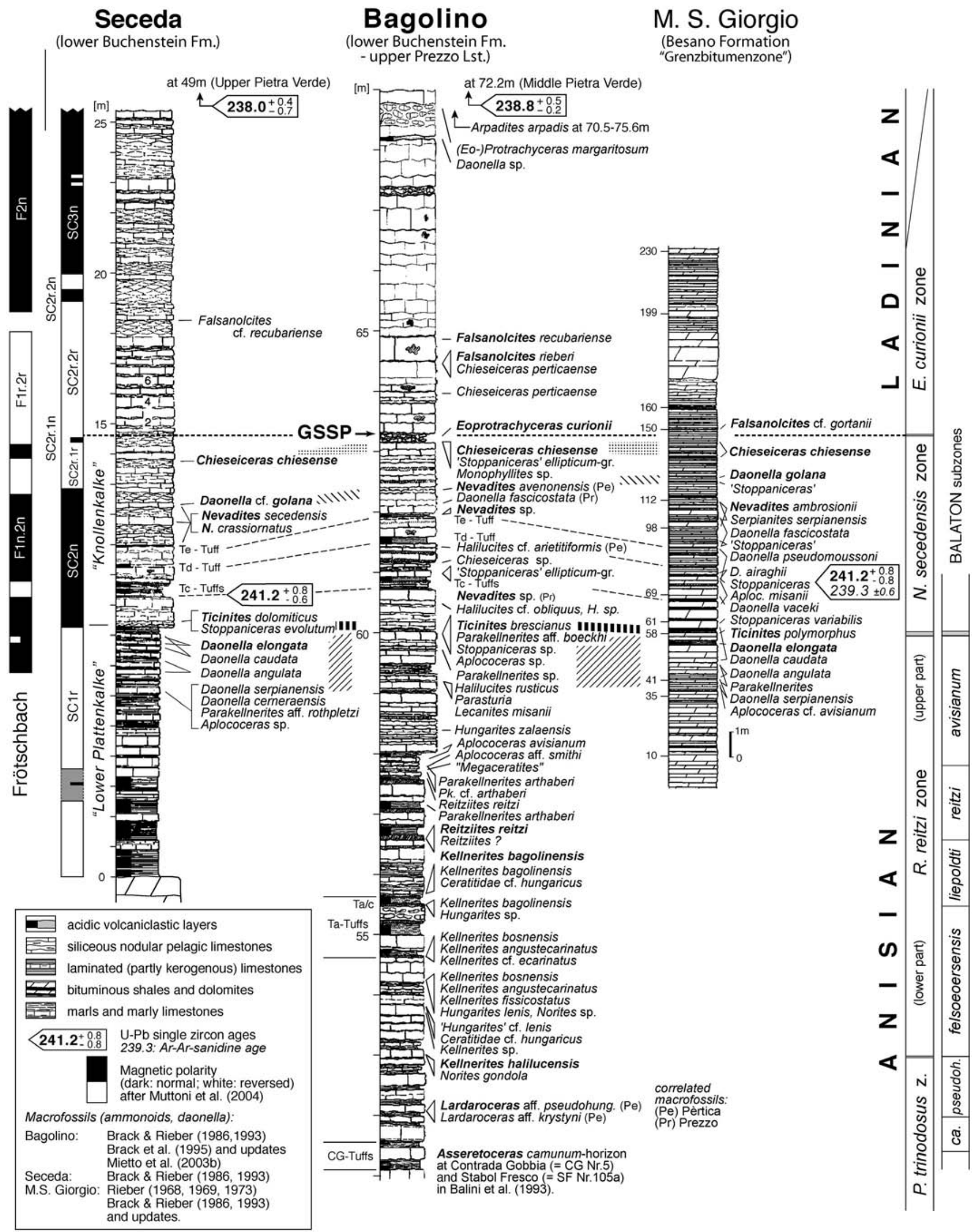

Figure 7 Compilation and correlation of stratigraphic results from important South Alpine sections in the Anisian/Ladinian boundary interval with indication of lithological markers (volcaniclastic layers, bedding patterns), magnetic reversals, radio-isotopic age data and the ranges of macrofossils (ammonoids, Daonella). The Seceda section is the principal auxiliary section in the Dolomites. Also shown is the correlation with the subzonal scheme of the Balaton Highland (Vörös et al., 2003a). 


\section{Biostratigraphy}

\section{Ammonoids and definitions of ammonoid zones}

In all sections studied thoroughly in eastern Lombardy and Giudicarie Eoprotrachyceras curionii (i.e., the principal biostratigraphic GSSP marker) occurs in a single layer and to date there is no evidence for the existence of older representatives of the genera Eoprotrachyceras or Protrachyceras. In the Western Tethys E. curionii is thus the oldest known representative of these genera and also marks the origination of the family Trachyceratidae. The ancestors of Eoprotrachyceras are as yet not known for sure. Silberling \& Nichols (1982) and Tozer (1994a) consider the Ceratitidae Nevadites and Paranevadites as possible precursors. Alternative ancestors of Eoprotrachyceras (and, therefore, of the family Trachyceratidae) are representatives of Ticinites or Falsanolcites, the latter being likely stratigraphically young members of the family Ceratitidae. Representatives of Falsanolcites and other genera of the subfamily Nevaditinae TOZER, 1994 share important morphological characters with, and have a FAD predating that of Eoprotrachyceras (Rieber \& Brack, 2004).

In the GSSP-section at Bagolino the ammonoid record is particularly well established also above and below the GSSP-level (Figures 5 and 6). Within the Brescian Prealps and Giudicarie, layers containing ammonoids with a short stratigraphic range such as Falsanolcites recubariense, $F$. rieberi, Chieseiceras perticaense above, and the last Ceratitidae ('Stoppaniceras' ellipticum-gp.), Nevadites and Ticinites below the GSSP-level allow firm correlations of an extended Anisian/ Ladinian boundary interval (Brack \& Rieber, 1986, 1993; Brack et al., 1995). The fossil record below the layers with Ticinites provides excellent correlation of sections in the Southern Alps with those in Hungary (Figure 8).

The ammonoid zones referred to in this paper (Figure 6) are considered to be assemblage zones and are named after a typical ammonoid species. Following Brack \& Rieber (1993, 1994) and Rieber \& Brack (2002) the base of the $R$. reitzi Zone (= Reitziites reitzi Zone) is defined by the appearance of the genus Kellnerites, the base of the $N$. secedensis Zone (= Nevadites secedensis Zone) by the appearance of the genus Ticinites and the base of the E. curionii Zone (= Eoprotrachyceras curionii Zone) by the appearance of the genus Eoprotrachyceras, respectively. However, alternative but partly inconsistent current schemes of ammonoid zones and subzones for the Anisian/Ladinian boundary interval differ from these definitions. In agreement with our scheme, Vörös et al. (1996) and Vörös (1998) used an equivalent $R$. reitzi Zone including the four subzones, named felsoeoersensis, liepoldti, reitzi, avisianum and with its base placed at the appearance of Kellnerites. However, Vörös et al. (2003a) have reduced the range of their $R$. reitzi Zone which only comprises the unchanged reitzi and avisianum Subzones. In a modified version of the scheme of ammonoid zones and subzones by Mietto \& Manfrin (1995), Mietto et al. (2003a) and Manfrin et al. (2005) suggest the following sequence of subzones: reitzi, avisianum, crassus, secedensis, chiesense, curionii, recubariensis. In this scheme the reitzi and avisianum Subzones largely correspond to the lower and upper parts of our $R$. reitzi Zone with the base of the
Felsöörs (Balaton Highland)

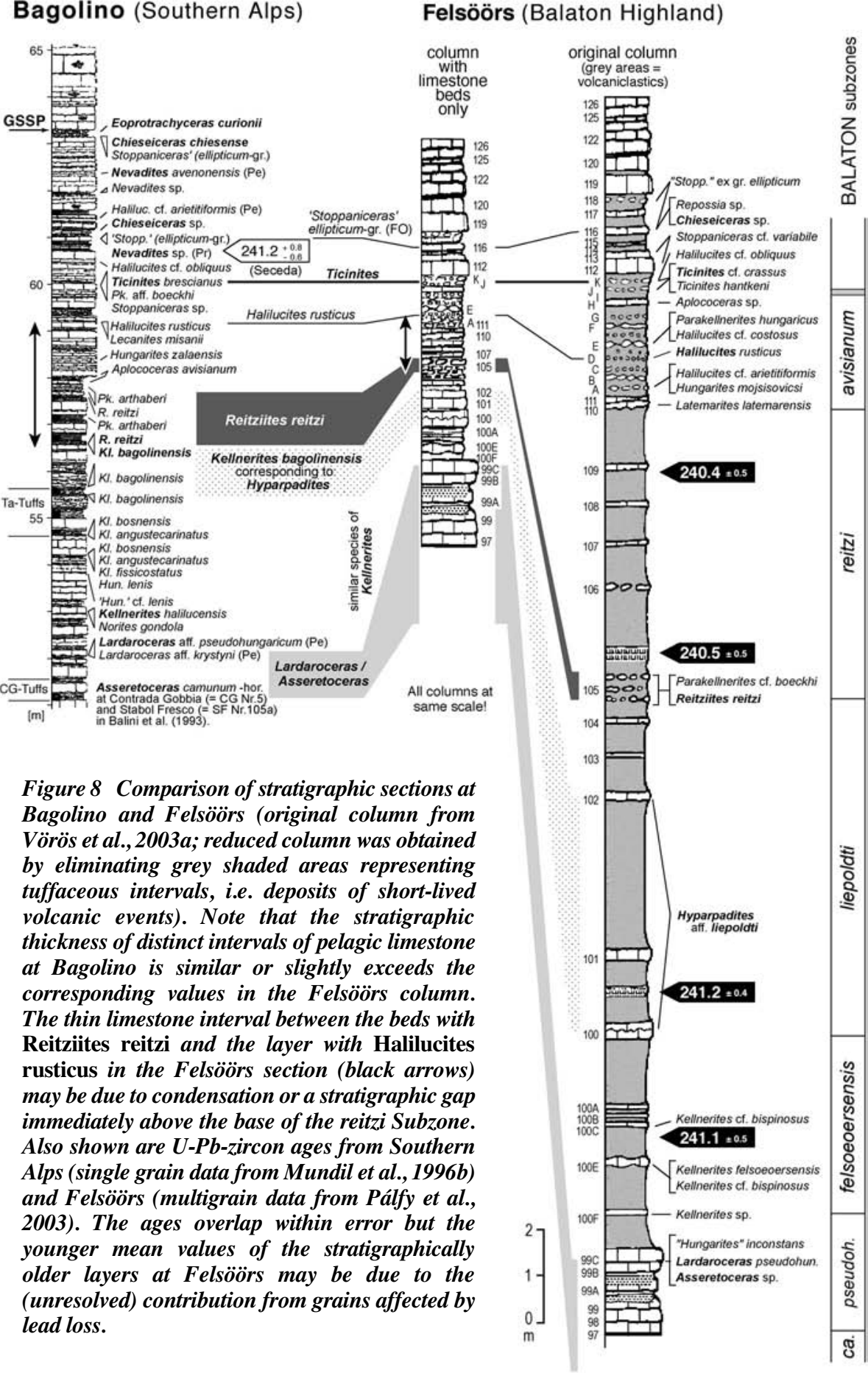

avisianum Subzone defined by the FAD of Aplococeras avisianum inferred to be at the $57.7 \mathrm{~m}$-level of the Bagolino reference scale (Figures 6 and 7). The base of the crassus Subzone (lowermost subzone of their Nevadites Zone) is defined by the FAD of Halilucites (Mietto et al., 2003a) at the $59.2 \mathrm{~m}$-level, i.e. clearly below the base of our $N$. secedensis Zone $(60 \mathrm{~m}-\mathrm{level})$. At Bagolino the base of the secedensis Subzone of Manfrin et al. (2005; = serpianensis Sz. in Mietto \& Manfrin, 1995) may be located slightly above the $62 \mathrm{~m}$-level (i.e., above the Te-tuff layer) and hence falls in the upper half of the $N$. secedensis Zone. The chiesense Subzone of Mietto et al. (2003a) is restricted to a narrow interval between the $63 \mathrm{~m}$-level and the GSSP-horizon and the curionii to recubariensis Subzones largely correspond to the E. curionii Zone (Figures 3 and 6). Note that in spite of the good agreement of the ammonoid successions, the Hungarian avisianum Subzone also covers the lower part of the crassus Subzone sensu Mietto et al. (2003a). 


\section{Conodonts}

The conodont distribution at Bagolino (Nicora \& Brack, 1995; Brack \& Nicora, 1998) complemented with data from accurately correlated additional sections (Stabol Fresco: Kovács et al., 1990 and updates; Pèrtica, Brozzo: Nicora \& Brack, in prep.), and also including results from the Dolomites (Muttoni et al., 2004b), indicates the following "conodont events" in the Anisian/Ladinian boundary interval (Figure 6): (1) Close to the base of the $R$. reitzi Zone, Neogondolella cornuta postcornuta and the group of Paragondolella alpina appear among other taxa; (2) In the upper $R$. reitzi Zone, Paragondolella fueloepi and Paragondolella trammeri appear for the first time; (3) In the upper part of the N. secedensis Zone, Neogondolella praehungarica appears together with a precursor form of Budurovignathus gabriellae provisionally referred to here as Neogondolella sp. A; (4) Budurovignathus truempyi and B. hungaricus occur in layers corresponding to the $66 \mathrm{~m}$-level of the Bagolino reference column or higher up.

\section{Daonella, radiolarians, palynomorphs and foraminifera}

Only a few well preserved specimens of biostratigraphically relevant thin shelled bivalves Daonella have been extracted from the Anisian/Ladinian boundary interval in sections around Bagolino. Of these, Daonella fascicostata was found in the upper $N$. secedensis Zone immediately above the Te-tuff layer at Prezzo. Figure 7 highlights the close match of the distribution of Daonella of the group of D. elongata (D. serpianensis-angulata-caudata-elongata-airaghii) in other South Alpine sections.

No determinable Daonella are known so far from the E. curionii Zone. Stratigraphically higher, different species of Daonella are precisely located in layers of the middle $(D$. cf. longobardica, $D$. moussoni) and upper Buchenstein Formation (D. taramellii, D. pichleri, D. tyrolensis) at Bagolino, M. Corona and Seceda (Brack et al., 2000; Schatz, 2001a,b; Maurer \& Rettori, 2002).

Numerous, but hitherto unreported species of radiolarians have been detected in samples from the Buchenstein Formation at Seceda and Frötschbach (H. Kozur, pers. commun.). Of these, the radiolarians from the uppermost "Plattenkalke" with Daonella of the elongata-group (lower Buchenstein Formation; Figure 7) are attributed to the Oertlispongus inaequispinosus Subzone (upper Spongosilicarmiger italicus Zone). The most complete available radiolaria succession is known from the Recoaro area (Kozur \& Mostler, 1994) the onset of which is in the $R$. reitzi Zone. Above the R. reitzi Zone this record lacks an adequate ammonoid control.

First results on palynomorphs from the Buchenstein Formation of the Seceda core (Dolomites) along with revised data from Val Gola suggest a distinct change in the microflora between assemblages observed in the "Lower Plattenkalke" (upper R. reitzi Zone) and in the "Knollenkalke" of the upper E. curionii Zone (Hochuli \& Roghi, 2002 and in prep.). A detailed record of mainly platformderived benthic foraminifera associated with open-marine foraminifera in turbidite beds from the Seceda core spans the entire Buchenstein Formation above the upper R. reitzi Zone (Maurer \& Rettori, 2002). This record shows its most important biostratigraphic event with the appearance of the family Involutinidae well above the GSSP-level, i.e. above the E. curionii Zone.

\section{Tephrastratigraphy}

Volcaniclastic layers occur at Bagolino as light grey to white illite-rich silt layers in the uppermost Prezzo Limestone ([Contrada Gobbia] CG-tuffs") and in the "transitional beds" (Ta-tuffs). In the upper part of the latter interval (Tb-tuffs) and throughout the entire Buchenstein succession, a few (millimeters up to a few decimeters) acidic ash beds, often with a greenish colour ("Pietra verde"), occur with increased frequencies in three stratigraphic intervals $(56-62 \mathrm{~m}$; 68-76m; 82-92m; see fig. 7 in Brack \& Rieber, 1993). Individual beds and characteristic stacks of layers can be traced over tens of kilometres and have been identified as far away as in the Dolomites and in Southern Switzerland (Figure 7; see also figs.7,10,11 in Brack \& Rieber, 1993 and figs.2,3,11 in Brack \& Muttoni, 2000). The lateral persistence of volcaniclastic layers in combination with the occurrence of accretionary lapilli indicate an airborne origin of the silt to sand-sized ash particles, probably originating from eruption centres located mainly outside the present Southern Alps.

Beyond their occurrence in South Alpine basinal sediments and platform interior carbonates (e.g., at Latemar; Mundil et al., 2003), comparable volcaniclastic ash layers suitable for radio-isotopic age dating and stratigraphic correlation are known from the Reifling Beds and equivalent units of the Eastern Alps (e.g., Brühwiler, in prep.) as well as from sedimentary successions further afield (e.g., Hungary, Dinarids, Greece).

\section{Geochronometry}

High-resolution $\mathrm{U}-\mathrm{Pb}$ age data obtained on single zircon grains from volcaniclastic layers are available for four distinct stratigraphic horizons in Buchenstein and corresponding layers at Bagolino, Seceda and M.S. Giorgio (Figs.3,5,6; Mundil et al., 1996b,c; Brack et al, 1996). The GSSP-level is bracketed by the age values for the Tc-tuff interval ( $N$. secedensis Zone; SEC.22: 241.2+0.8/-0.6 Ma and MSG.09: 241.2 $\pm 0.8 \mathrm{Ma}$; uncertainties at $95 \%$ confidence level) below and for a volcaniclastic layer with accretionary lapilli at the 72.2m-level of Bagolino (BAG.06a: 238.8+0.5/-0.2 Ma) above. The age of the Tc-tuff interval is supported by zircon ages of three largely age-equivalent tuff layers in a thick platform interior carbonate succession at Latemar with the following values in ascending stratigraphic order: LAT31: 242.6 $\pm 0.7 \mathrm{Ma}$; LAT30: 241.2+0.7/-0.6 Ma; LAT32: $241.7+1.5 /-0.7 \mathrm{Ma}$ (Mundil et al., 2003). The age of the Latemar tuffs is constrained by ammonoids indicative of the upper $R$. reitzi to $N$. Secedensis Zone (Mundil et al., 2003; Manfrin et al., 2005) and the youngest dated horizon (LAT32) may indeed closely correspond to the Tc-Te-tuffs of the Buchenstein succession. Moreover, the error bars of the zircon ages of the Tc-tuff interval overlap with multigrain $\mathrm{U}-\mathrm{Pb}$-ages from stratigraphically somewhat older tuff layers at Felsöörs (Pálfy et al., 2003; Vörös et al., 2003a). An independent $\mathrm{U}-\mathrm{Pb}$ zircon study on crystals from volcaniclastic layers in South Alpine Buchenstein sections (including Bagolino) yields results which are in agreement with the above mentioned $\mathrm{U}-\mathrm{Pb}$ data (S. Bowring, pers. commun.). As pointed out in Mundil et al. (1996b), the above cited U-Pb ages must be considered minimum ages due to the age lowering effects of secondary $\mathrm{Pb}$ loss. A reexamination of the previously analyzed horizons applying modern pre-treatment techniques (Mundil et al., 2004, Mattinson, 2005) may yield slightly older but more accurate age results.

\section{Magnetostratigraphy}

Samples taken for magnetostratigraphic analyses at Bagolino show remagnetised Tertiary components (G. Muttoni, pers. commun.). The succession of magnetic reversals is well established for almost the entire succession of the Buchenstein Formation in correlated sections in the Dolomites (Muttoni et al., 1997, 2004b; Brack \& Muttoni 2000) and at Val Gola (Gialanella et al., 2001; Brack et al., 2001). In this record of magnetic reversals (Figure 7), the GSSPlevel lies close to the base of the reversed magnetozone SC2r.2r at Seceda and correlative magnetozones. This magnetozone is preceded by the short normal polarity interval SC2r.1n.

\section{Chemical stratigraphy}

Unpublished results of a pilot study of stable isotopes (carbon, oxygen) on 30 outcrop samples, evenly distributed over the entire succession of the Buchenstein Formation at Seceda, show lithologyrelated variation in the carbon isotopes ( $\mathrm{R}$. Abart, pers. commun.). Throughout the entire column no significant excursion is evident in the oxygen isotopes with a mean value of $\delta^{18} \mathrm{O}(\mathrm{PDB})$ of $-2.82+/-0.78 \%$. This range is in good agreement with $\delta^{18} \mathrm{O}$ data from a Buchenstein section in the central Dolomites (Rio Sacuz) which is thought to correspond in age with mainly the lower part of the "Knollenkalke" at Seceda (Preto et al., 2005). 
${ }^{87} \mathrm{Sr} /{ }^{86} \mathrm{Sr}$-ratios of conodonts from the $N$. secedensis to $E$. curionii Zone interval in equivalent Buchenstein-type lithologies ("Knollenkalke") in Hungary (Felsöörs, Köveskal) fall in the range between $0.707664-0.707716$, with a tendency of decreasing values up section (Korte et al., 2003).

\section{Sequence stratigraphy and cyclostratigraphy}

The deposition of the pelagic Buchenstein Formation occurred in deep marine conditions. The careful calibration of platform-basin settings in the Dolomites (Maurer 1999, 2000; Brack \& Muttoni, 2000 ) indicates a maximum basin depth close to the base of the E. curionii Zone (i.e. close to the GSSP-level).

The spectral analysis of bedding rhythms in distinct intervals of the Buchenstein Formation in the Seceda core and section (Maurer et al., 2004) potentially indicates the existence of hierarchical stacking patterns possibly related to variations in orbital parameters. If confirmed and extended, these results could be suitable for a significant refinement of the age resolution in the "Knollenkalk"-interval of the Buchenstein Formation, i.e. from the $N$. secedensis Zone upwards and including the GSSP-level.

\section{Regional and global correlation of Anisian/Ladinian boundary successions and of the GSSP-level}

Litho-, tephra- and biostratigraphy allow detailed correlation of Anisian/Ladinian boundary intervals of sections in the Brescian Prealps (including Bagolino), Giudicarie and southern Switzerland (Brack \& Rieber, 1986, 1993). With a comparable bed-scale resolution, distinct intervals in sections of the Buchenstein Formation in the Dolomites are correlated on the basis of stratal patterns and magnetostratigraphy (Brack \& Muttoni, 2000; Muttoni et al., 2004b). Good correspondence of fossils (ammonoids, conodonts) is also recognized below the Ticinites horizon at Bagolino and in the Balaton Highland (e.g., Felsöörs; Figure 8). This is supported by the recognition of the Oertlispongus inaequispinosus radiolarian Subzone (upper Spongosilicarmiger italicus Zone) in the uppermost "Plattenkalke" at Seceda (H. Kozur, pers. commun.) and in layers 110-111C at Felsöörs (Vörös et al., 2003a). The expansion of the stratigraphic interval of the R. reitzi Zone at Felsöörs (Vörös, 1998; Vörös et al., 2003a) is due to dilution with abundant volcaniclastic material. The cumulative thickness of fossil-bearing limestone layers is comparable in both sections, but at Felsöörs the GSSP-level (i.e. the base of E. curionii Zone) still lacks an adequate documentation by ammonoids.

Outside the realm including the Southern Alps and the Balaton Highland, the GSSP-level is recognized on the basis of ammonoids, e.g., in Greece. In particular, the ammonoid record of the Anisian/Ladinian boundary interval of the condensed red Hallstatttype limestone at Epidavros (Krystyn, 1983; unpublished own data) is in good agreement with the sequence of fossils at Bagolino. Common or similar taxa include representatives of Kellnerites, Nevadites, Falsanolcites, Chieseiceras (e.g., Chieseiceras chiesense), Eoprotrachyceras, Arpadites. At Epidavros the GSSP-level is identified by the occurrence of Eoprotrachceras but the comparison with Bagolino also suggests significant condensation in the E. curionii Zone at Epidavros.

An ammonoid based correlation of South Alpine pelagic successions (including Bagolino) with the Germanic Middle Triassic (e.g., Brack et al., 1999) is hampered by endemism of the faunas in the Germanic Upper Muschelkalk. Magnetostratigraphic information from an incompletely preserved succession of Upper Muschelkalk at Nietulisko in Poland (Navrocki \& Szulc, 2000) ends presumably at around the GSSP-level. In this section the "Cycloides"-level is located in the uppermost metre of the Ceratites Beds as recorded by Navrocki \& Szulc (2000), i.e. in the reversed polarity chron HC4r (J. Szulc, pers. commun.). A correspondence of magnetic reversal $\mathrm{HC} 3 \mathrm{n} / \mathrm{HC} 4 \mathrm{r}$ at Nietlusko and reversal SC2n/SC2r.1r in the upper part of the $N$. secedensis Zone at Seceda (Figure 7) seems to be in agreement with the distributions of Paragondolella trammeri. According to Aigner \& Bachmann (1992) the "Cycloides gamma"-horizon of the Germanic realm marks a maximum flooding surface and this horizon may indeed correspond to an interval of maximum basin depth at around the GSSP level in the Southern Alps (Brack et al., 1999).

Trans-Panthalassan correlation of Anisian/Ladinian boundary intervals in the Southern Alps and North America (Nevada, British Columbia) are established on the basis of equivalent genera and similar species of ammonoids and Daonella (e.g., Nevadites, Eoprotrachyceras, Daonella of D. elongata-group) as well as of conodonts ( $N$. constricta $+N$. alpina, $N$. praehungarica, $P$. (aff.) fueloepi; e.g., Brack \& Rieber, 1994; Bucher \& Orchard, 1995). In particular, the appearance of $N$. praehungarica and its co-occurrence with $P$. fueloepi in the upper part of the $N$. secedensis Zone, just below the GSSP-level, seems at present to be the only suitable marker for conodontbased correlation with data from Nevada and British Columbia (Bucher \& Orchard, 1995; Orchard \& Tozer, 1997). All these fossils confirm the close correspondence of the upper $R$. reitzi Zone to $E$. curionii Zone interval of the Western Tethys with the upper part of the meeki Zone to lower subasperum Zone of Nevada. In North America (Nevada, British Columbia) the GSSP-level is recognized by the onset of representatives of the genus Eoprotrachyceras. According to Tozer (1994b) stratigraphically deeper levels cannot yet be correlated in detail with British Columbia. The Triassic successions of northeastern British Columbia also provide a biostratigraphic link of low latitude and Arctic Middle Triassic successions (Dagys \& Weitschat, 1993). Nevertheless, precise macro- and microfossil-based correlations of Upper Anisian to Lower Ladinian successions from all these realms still remain to be established and the correspondence of stratigraphic sequences between low and high latitude successions still lacks adequate age constraints.

Only little information seems to exist to date on fossiliferous pelagic Anisian/Ladinian boundary intervals with sufficiently detailed records of either ammonoids, Daonella or conodonts in Asia and elsewhere. A few ammonoids attributable to the upper $N$. secedensis and E. curionii Zones are reported from Himalayan successions (e.g. Spiti). Daonella and/or ammonoids are known from scattered places throughout south-east Asia (e.g., Vietnam) whereas Daonella-bearing volcaniclastic-rich Middle Triassic sediments in New Zealand formed at higher-paleolatitudes.

The occurrence of undisputed representatives of the D. elongatagroup in China (D. cf. airaghii) and in the meeki Zone of Nevada (Daonella cf. elongata; Silberling \& Nichols, 1982 and new unpublished own finds) emphasizes the potential of these bivalves in longdistance correlations of Anisian/Ladinian boundary layers. Other fossils such as radiolarians may also gain significance. For instance, the Oertlispongus inaequispinosus radiolarian Subzone known throughout the Tethys has also been recognized in ammonoid-free and mostly conodont-free low latitude oceanic radiolarite successions of Panthalassa (Japan, Philippines; H. Kozur, pers. commun.).

Correlation of marine and non-marine Anisian/Ladinian boundary intervals of comparable climate zones may soon be facilitated by improved knowledge on the ranges of palynomorphs. If confirmed and properly positioned, the distinct change in microflora assemblages between the upper $R$. reitzi Zone and the upper E. curionii Zone at Seceda and in associated sections (Hochuli \& Roghi, 2002 and in prep.) could possibly serve as an approximation of GSSP-level.

\section{The age of the Ladinian GSSP in the context of the Triassic time scale}

We intend to draw the attention of the "casual user" of time-scale compilations to the calibration of the Triassic which has been particularly controversial. Probably because radio-isotopic ages presented in Mundil et al. (1996b,c) did not agree with time estimates based on cycle counts in carbonate platform interior sediments at Latemar (e.g., Hinnov \& Goldhammer, 1991; Preto et al., 2001, 2004) the for- 
mer age data were considered "ambiguous". Even though the radioisotopic ages on the Pietra Verde horizons have been confirmed by the same and other research groups (Palfy et al., 2003, Mundil et al., 2003, see above), they have been largely ignored even in the most recent time scale compilation for the Triassic (Gradstein et al., 2004a,b). Moreover, the age of $c a 241$ Ma proposed in Mundil et al. $(1996 \mathrm{~b}, \mathrm{c})$ for the base of the Ladinian is in excellent agreement with new U-Pb zircon ages of volcaniclastic layers at the Permian/Triassic boundary and in Lower Triassic to Anisian successions in China (Lehrmann et al, 2005; Ovtcharova et al., 2005). These high-quality age data for the Lower Triassic along with recently calibrated cyclostratigraphic constraints for the Upper Triassic call for a revision of the Triassic part of the GTS 2004 time scale (Gradstein et al., 2004a,b; Ogg, 2004).

We feel therefore prompted to suggest a Triassic time scale (Figure 9) which is based on the following constraints:

1) The age for the base of the Jurassic System is placed at $c a 201 \mathrm{Ma}$ following Pálfy et al. (2000a, 2000b) and also considering U-Pb age data from magmatic rocks in continental settings (Hodych \& Dunning, 1992) although the application of modern techniques may reveal that the boundary age is slightly older (Mundil et al., 2004, Mattinson 2005)

2) The age calibration of the Newark magnetostratigraphy (Kent \& Olsen, 1999) through correlation with Slowakia (Channel et al., 2003) and Sicily ("long Norian option" of Muttoni et al., 2004a) result in numeric ages around 207 and $226 \mathrm{Ma}$ for the base of the Rhaetian and Norian Stages respectively.

3) The poorly constrained base of the Carnian Stage is provisionally placed at $235 \mathrm{Ma}$. Constraints are indirect and provided by i) a $>230 \mathrm{Ma}$ age for the (Carnian) base of the cyclic Newark stratigraphy, and ii) by the 237.3+0.4/-1.0 Ma U-Pb-zircon age of Upper Ladinian intrusive rocks in the Dolomites (Predazzo; see Mundil et al., 1996a, Brack et al., 1997). The Predazzo granites crosscut rocks of the Ladinian Buchenstein and Wengen Formations. Upwards the (mainly turbiditic) Wengen Fm. grades into the lithologically similar S. Cassian Formation which latter, in its lowermost part, hosts a candidate for the GSSP of the base of the Carnian (Broglio Loriga et al., 1999).

4) The base of the Ladinian (= current GSSP-level) falls in the 240-242 Ma interval as indicted above.

5) New U-Pb single zircon data from biostratigraphically constrained sediments (ammonoids, conodonts) of Early Triassic (Induan) to Early Anisian age (Lehrmann et al, 2005; Ovtcharova et al., 2005) indicate an age of $c a 248 \mathrm{Ma}$ for the base of the Anisian.

6) The 252.6 Ma age for the base of the Triassic System is adopted from Mundil et al. (2004).

The majority of Triassic GSSP's still need to be fully discussed and agreed upon and stratigraphic uncertainty may therefore be in most cases considerable but difficult to quantify.

\section{Acknowledgments}

We would like to thank all people involved in the long process of defining the base of the Ladinian for stimulating discussions and scientific and moral support. In 1993, M. Gaetani initiated the formal discussion and decision process. Later on A. Baud led the Anisian/Ladinian boundary working group whose discussions significantly contributed to the GSSP decision. STS-chairman Mike Orchard and ICS-officer James G. Ogg thoroughly reviewed the final GSSP proposal. Mike Orchard also reviewed this final report.

\section{References:}

Aigner, T., and Bachmann, G.H., 1992, Sequence stratigraphic framework of the German Triassic: Sed. Geol., v. 80: 115-135.

Arthaber, G.v., 1906, Die alpine Trias des Mediterran-Gebietes, in Frech, F., ed, Lethaea geognostica, pt.2 Das Mesozoicum 1 (Trias), pp. 223-475.

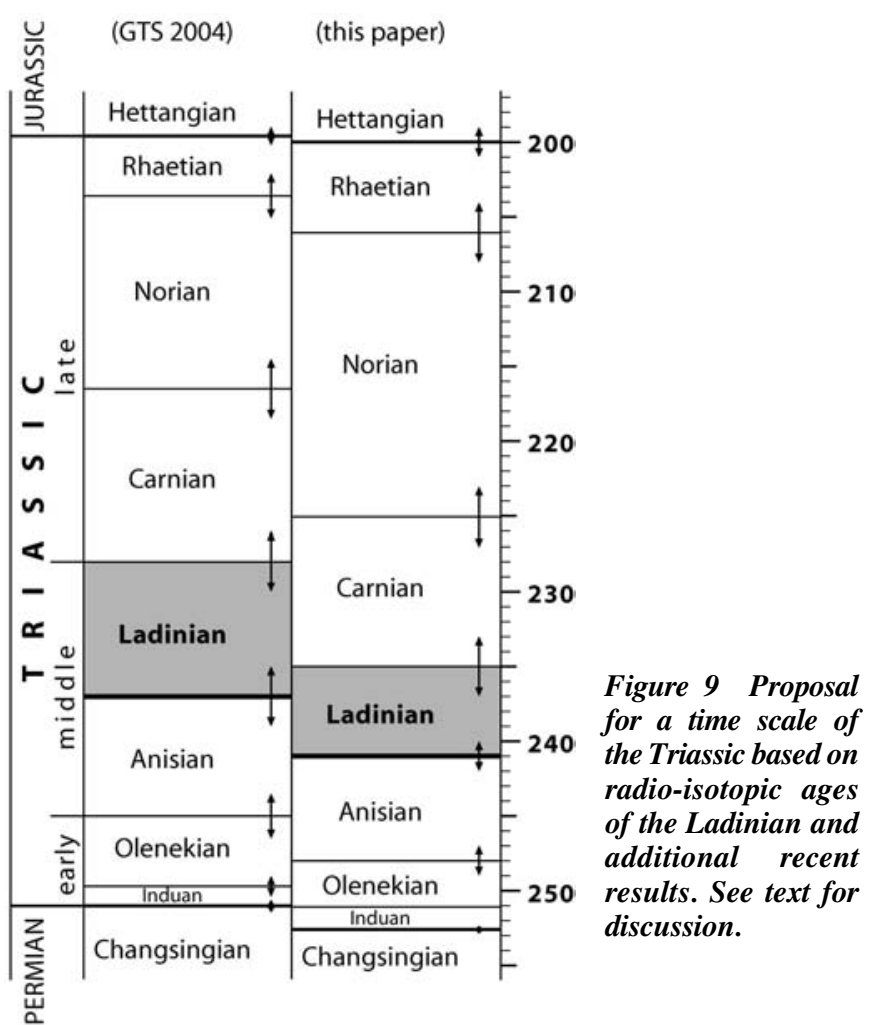

Balini, M., 1998, Taxonomy, stratigraphy and phylogeny of the new genus Lanceoptychites (Ammonoidea, Anisian): Riv. It. Paleont. Strat., v. 104, no. 2 , pp. 143-166.

Balini, M., Gaetani, M., and Nicora, A., 1993, Excursion Day 2, in Gaetani, M., ed, Anisian/Ladinian boundary field workshop Southern Alps - Balaton Highlands, 27 June - 4 July 1993; Field-guide book. I.U.G.S. Subcommission of Triassic Stratigraphy; pp. 43-54.

Bittner, A., 1881, Über die geologischen Aufnahmen in Judikarien und Val Sabbia. Jb. k.k. geol. Reichsanst., v. 31, no. 3, pp. 219-370.

Bittner, A., 1892, Was ist norisch? Jb. k.k. geol. Reichsanst., v. 42, no. 3, pp. 387-396.

Brack, P., and Muttoni, G., 2000, High-resolution magnetostratigraphic and lithostratigraphic correlations in Middle Triassic pelagic carbonates from the Dolomites (northern Italy). Palaeogeogr., Palaeoclim., Palaeoecol., v. 161 , no. 3-4, pp. 361-380.

Brack, P., and Nicora, A., 1998, Conodonts from the Anisian-Ladinian succession of Bagolino, Brescian Prealps (Brescia, Lombardy, Northern Italy). Giorn. Geol., ser.3, 60, 1998, Spec. Issue, ECOS VII- Southern Alps Field Trip Guidebook, pp. 314-325.

Brack, P., and Rieber, H., 1986, Stratigraphy and ammonoids from the lower Buchenstein Beds in the Brescian Prealps and Giudicarie and their significance for the Anisian/Ladinian boundary. Eclogae geol. Helv., 79, v. pp. 181-225.

Brack, P., and Rieber, H. 1993, Towards a better definition of the Anisian/Ladinian boundary: New biostratigraphic data and correlations of boundary sections from Southern Alps. Eclogae geol. Helv., v. 86, pp. 415-527.

Brack, P., and Rieber, H., 1994, The Anisian/Ladinian boundary: retrospective and new constraints. Albertiana, v. 13, pp. 25-36.

Brack, P., Mundil, R., Oberli, F, Meier, M., and Rieber, H. 1996, Biostratigraphic and radiometric age data question the Milankovitch characteristics of the Latemar cycles (Southern Alps, Italy). Geology, v. 24, no. 4, pp. 371-375.

Brack, P., Mundil, R., Oberli, F., Meier, M., and Rieber, H., 1997, Biostratigraphic and radiometric age data question the Milankovitch characteristics of the Latemar cycles (Southern Alps, Italy). Reply, Geology, v. 25, no. 5, pp. 471-472.

Brack, P., Muttoni, G., and Rieber, H., 2001, Comment on: 'Magnetostratigraphy and biostratigraphy of the Middle Triassic Margon section (Southern Alps, Italy)' by P.R. Gialanella. F. Heller, P. Mietto, A. Incoronato, V. De Zanche, P. Gianolla, G. Roghi [Earth Planet. Sci. Lett. 187 (2001) 17-25]. Earth Planet. Sci. Lett., v. 193, no. 1-2, pp. 255-257.

Brack, P., Rieber, H., and Mundil, R., 1995, The Anisian/Ladinian boundary interval at Bagolino (Southern Alps, Italy): I. Summary and new results on ammonoid horizons and radiometric age dating. Albertiana, v. 15, pp. $45-56$ 
Brack, P., Rieber, H., and Nicora, A., 2003, The Global Stratigraphic Section and Point (GSSP) for the base of the Ladinian Stage (Middle Triassic). A proposal for the GSSP at the base of the Curionii Zone in the Bagolino section (Southern Alps, Northern Italy). Albertiana, v. 28, pp. 13-25.

Brack, P., Rieber, H., and Urlichs, M., 1999, Pelagic successions in the Southern Alps and their correlation with the Germanic Middle Triassic. Zbl. Geol. Paläont. Teil I (1998), H. 7-8, pp. 853-876.

Brack, P., Schlager, W., Stefani, M., Maurer, F., and Kenter, J., 2000, The Seceda Drill Hole in the Middle Triassic Buchenstein beds (Livinallongo Formation, Dolomites, Northern Italy) - a progress report. Riv. It. Paleont. Strat., v. 106, no. 3, pp. 283-292.

Broglio Loriga, C., Cirilli, S., De Zanche, V., Di Bari, D., Gianolla, P., Laghi, G.F., Lowrie, W., Manfrin, S., Mastandrea, A., Mietto, P., Muttoni, G., Neri, C., Posenato, R., Reichichi, M., Rettori, R., and Roghi, G., 1999, The Prati di Stuores/Stuores Wiesen Section (Dolomites, Italy): A candidate Global Stratigraphic Section and Point for the base of the Carnian stage. Riv. It. Paleont. Strat., v. 105, pp. 37-78.

Brühwiler, T., Schatz, W., Hochuli, P.A., Mundil, R., and Brack, P., (in prep.), Bio- and chronostratigraphy of the Middle Triassic Reifling Beds in Austroalpine units of Vorarlberg /Austria) and Lichtenstein and the correlation with corresponding successions in the Southern Alps (northern Italy).

Bucher, H., and Orchard, M.J., 1995, Intercalibrated ammonoid and conodont succession, Upper Anisian- Lower Ladinian of Nevada. Albertiana, v. 15 , pp. 66-71.

Channell, J.E.T, Kozur, H.W., Sievers, T., Mock, R., Aubrecht, R., and Sykora, M., 2003, Carnian-Norian biomagnetostratigraphy at Silicka Brezova (Slovakia): correlation to other Tethyan sections and to the Newark Basin, Palaeogeogr. Palaeoclim. Palaeoecol., v. 191, pp. 65-109.

Dagys, A., and Weitschat, W., 1993, Correlation of the Boreal Triassic. Mitt. Geol.-Paläont. Inst. Univ. Hamburg., v. 75, pp. 249-256.

Gaetani, M., ed, 1993, Anisian/Ladinian boundary field workshop Southern Alps - Balaton Highlands, 27 June-4 July 1993; Field-guide book. I.U.G.S. Subcommission of Triassic Stratigraphy; $118 \mathrm{pp}$.

Gallet, Y., Krystin, L., and Besse, J., 1998, Upper Anisian to Lower Carnian magnetostratigraphy from the Northern Calcareous Alps (Austria). J. geophys. Res., v. 103, no. B1, pp. 605-621.

Gialanella, P.R., Heller, F., Mietto, P., Incoronato, A., De Zanche, V., Gianolla, P., and Roghi, G., 2001, Magnetostratigraphy and biostratigraphy of the Middle Triassic Margon section (Southern Alps, Italy). Earth Planet. Sci. Lett., v. 187, pp. 17-25

Gradstein, F.M., Ogg, J.G., Smith, A.G., Bleeker, W., and Lourens, L., 2004a, A new geologic Time Scale, with special reference to Precambrian and Neogene. Episodes, v. 27/2, pp. 83-100.

Gradstein, F.M., Ogg, J.G., and Smith, A.G., eds, 2004b, A geologic Time Scale 2004, Cambridge Univ. Press, 589 pp.

Hinnov L.A., and Goldhammer, R.K., 1991, Spectral analysis of the Middle Triassic Latemar Limestone. J. Sed. Petrol., v. 61, pp. 1173-1193.

Hochuli, P.A., and Roghi, G., 2002, A palynological view on the Anisian/Ladinian boundary-new results from the Seceda section (Dolomites, Northern Italy). STS/IGCP 467 field meeting, Veszprém, Hungary, 5-8 September, 2002. Geological Institute of Hungary; Abstract volume, pp. 29-30.

Hodych, J.P. and Dunning, G.R. 1992, Did the Manicouagan impact trigger end-of-Triassic mass extinction? Geology, v. 20, pp. 51-54.

Kent, D., and Olsen, P.E., 1999, Astronomically tuned geomagnetic timescale for the Late Triassic. J. Geophys. Res., v. 104, pp. 12831-12841.

Korte, C., Kozur, H.W., Bruckschen, P., and Veizer, J., 2003, Strontium evolution of Late Permian and Triassic seawater. Geochim. Cosmochim. Acta, v. 67, no. 1, pp. 47-62.

Kovács, S., 1994, Conodonts of stratigraphical importance from the Anisian/Ladinian boundary interval of the Balaton Highland. Riv. Ital. Paleont. Strat., v. 99(4), pp. 473-514.

Kovács, S., Nicora, A., Szabó, I., and Balini, M., 1990, Conodont biostratigraphy of Anisian/Ladinian boundary sections in the Balaton Upland (Hungary) and in the Southern Alps. Courier Forsch. Inst. Senckenberg, v. 118 , pp. $171-195$.

Kozur, H., 1995, Remarks on the Anisian/Ladinian boundary. Albertiana, v. 15 , pp. 36-44.

Kozur, H., and Mostler, H., 1994, Anisian to middle Carnian radiolarian zonation and description of some stratigraphically important radiolarians. Geol. Paläont. Mitt. Innsbruck, Spec. vol. 2, pp. 39-255.

Krystyn, L., 1983, Das Epidaurus-Profil (Griechenland) - ein Beitrag zur Conodonten-Standardzonierung des tethyalen Ladin und Unterkarn, in Zapfe H., ed, Neue Beiträge zur Biostratigraphie der Tethys-Trias. Schriftenr. erdwiss. Komm. österr. Akad. Wiss., v. 5, pp. 231-258.

Krystyn, L., and Mariolakos, J., 1975, Stratigraphie und Tektonik der Hallstätter-Scholle von Epidauros (Griechenland). Sitzungsber. österr. Akad. Wiss. [math.-matw. K1., Abt. I], v. 184, pp. 181-195.

Lehrmann, D.J., Payne, J.L., Enos, P., Montgomery, P., Wei, J., Yu, Y., Xiao, J., and Orchard, M.J., 2005, Field Excursion 2: Permian-Triassic boundary and a Lower-Middle Triassic boundary sequence on the Great Bank of Guizhou, Nanpanjiang basin, southern Guizhou Province, Albertiana, v. 33, pp. 169-186.

Manfrin, S., Mietto, P., and Preto, N., 2005, Ammonoid biostratigraphy of the Middle Triassic Latemar platform (Dolomites, Italy) and its correlation with Nevada and Canada. Geobios, v. 38, pp. 477-504.

Mariani, E., 1906, Alcune osservazioni geologiche sui dintorni di Bagolino nella Valle del Caffaro. Rend. Ist. lomb. Sci. [Lett., Ser. 2], v. 39, no. 14, pp. 646-653.

Mattinson, J.M., 2005, Zircon U-Pb chemical abrasion ("CA-TIMS") method: Combined annealing and multi-step partial dissolution analysis for improved precision and accuracy of zircon ages. Chemical Geology, v. 220, pp. 47-66.

Maurer, F., 1999, Wachstumsanalyse einer mitteltriadischen Karbonatplattform in den westlichen Dolomiten (Südalpen). Eclogae geol. Helv., v. 92 , pp. 361-378.

Maurer, F., 2000, Growth mode of Middle Triassic carbonate platforms in the Western Dolomites (Southern Alps, Italy)., Sed. Geol., v. 134, pp. 275 286.

Maurer, F., and Rettori R., 2002, Middle Triassic foraminifera from the Seceda core (Dolomites, Northern Italy). Riv. It. Paleont. Strat., v. 108, no. 3, pp. 391-398.

Maurer, F., and Schlager W., 2003, Lateral variations in sediment composition and bedding in Middle Triassic interplatform basins (Buchenstein Formation, Southern Alps, Italy). Sedimentology, v. 50, pp. 1-22.

Maurer, F., Hinnov, L., and Schlager, W., 2004, Statistical time series analysis and sedimentological tuning of bedding rhythms in a Triassic basina succession (Southern Alps, Italy). SEPM Spec. Publ. No. 81, pp. 83-99.

Mietto, P., and Manfrin, S., 1995, A high resolution Middle Triassic ammonoid standard scale in the Tethys realm. A preliminary report. Bull. Soc. Géol. Fr., v. 166, no. 5, pp. 539-563.

Mietto, P., Gianolla, P., Manfrin, S., and Preto, N., 2003a, Refined ammonoid biochronostratigraphy of the Bagolino section (Lombardian Alps, Italy), GSSP candidate for the base of the Ladinian Stage. Riv. It. Paleont. Strat. v. 109 , no. 3, pp. 449-462.

Mietto, P., Manfrin, S., Preto, N., Gianolla, P., Krystyn, L., and Roghi, G., 2003b, Proposal of the Global Stratigraphic Section and Point (GSSP) for the base of the Ladinian Stage (Middle Triassic) - GSSP at the base of the Avisianum Subzone (FAD of Aplococeras avisianum) in the Bagolino section (Southern Alps. NE Italy). Albertiana, v. 28, pp. 26-34.

Mojsisovics, E.v., 1874, Faunengebiete und Faciesgebilde der Trias-Periode in den Ost-Alpen. Jahrb. k.k. geol. Reichsanst., v. 24, no. 1, pp. 81-134.

Mojsisovics, E.v., 1882, Die Cephalopoden der mediterranen Triasprovinz. Abh. k.k. geol. Reichsanst., v. 10, 322pp.

Mojsisovics, E.v., Waagen, W., and Diener, C., 1895, Entwurf einer Gliederung der pelagischen Sedimente des Trias-Systems. Sitzber. k. Akad. Wiss. Wien, v. 104, no. 1, pp. 1271-1302.

Mundil, R., Brack, P. and Laurenzi, M. 1996a, High-resolution U-Pb singlezircon age determinations: New contraints on the timing of Middle Triassic magmatism in the Southern Alps, in: Geologia delle Dolomiti, Società Geologica Italiana, riunione estiva, San Cassiano (Italy). Abstract.

Mundil, R., Brack, P., Meier, M., Rieber, H., and Oberli, F., 1996b, High resolution U-Pb dating of Middle Triassic volcaniclastics: Time-scale calibration and verification of tuning parameters for carbonate sedimentation. Earth and Planetary Science Letters, v. 141, pp. 137-151.

Mundil, R., Brack, P., Meier, M., Rieber, H. and Oberli, F. 1996c, Erratum: High resolution U-Pb dating of Middle Triassic volcaniclastics: Timescale calibration and verification for tuning parameters for carbonate sedimentation (vol 141, pg 137, 1996). Earth and Planetary Science Letters, v. 143 , p. 275

Mundil, R., Ludwig, K.R., and Renne P.R., 2004, Age and timing of the Permian mass extinction: $\mathrm{U} / \mathrm{Pb}$ dating of closed-system zircons. Science, $\mathrm{v}$ 305 , pp. $1760-1763$

Mundil, R., Zühlke, R., Bechstädt, T., Peterhänsel, A., Egenhoff, S.O., Oberli, F., Meier, M., Brack, P., and Rieber, H., 2003, Cyclicities in Triassic platform carbonates: synchronizing radio-isotopic and orbita clocks. Terra Nova, v. 15, pp. 81-87.

Muttoni, G., Kent, D.V., Brack, P., Nicora, A., and Balini, M., 1997, Middle Triassic magnetostratigraphy and biostratigraphy from the Dolomites and Greece. Earth Planet. Sci. Lett., v. 146, pp. 107-120.

Muttoni, G., Kent, D.V., Olsen, P.E., Di Stefano, P., Lowrie, W., Bernasconi, S.M., and Hernández, F.M., 2004a, Tethyan magnetostratigraphy from Pizzo Mondello (Sicily) and correlation to the Late Triassic Newark astrochronological polarity time scale. Geol. Doc. Am. Bull., v. 116, no., 9/10, pp. 1043-1058.

Muttoni, G., Nicora, A., Brack, P., and Kent, D.V. 2004b, Integrated Anisian/Ladinian boundary chronology. Palaeogeogr., Palaeoclim., Palaeoecol., v. 208, pp. 85-102.

Navrocki, J., and Szulc, J., 2000, The Middle Triassic magnetostratigraphy from the Peri-Tethys basin in Poland. Earth Planet. Sci. Lett., v. 182, pp $77-92$.

Nicora, A., and Brack, P., 1995, The Anisian/Ladinian boundary interval at Bagolino (Southern Alps, Italy): II. The distribution of Conodonts. Albertiana, v. 15 , pp. 57-65 
Nicora, A., and Brack, P, (in prep.), The conodont distribution in upper Anisian - Ladinian successions (Buchenstein Beds) with ammonoid control in eastern Lombardy and Giudicarie (Southern Alps, Northern Italy).

Ogg, J.G., 2004, The Triassic Period, in Gradstein, F., Ogg, J.G., and Smith, A.G., eds, A geologic Time Scale 2004, Cambridge Univ. Press, pp. 271306 .

Orchard, M.J., and Tozer, E.T., 1997, Triassic conodont biochronology, its calibration with the ammonoid standard, and a biostratigraphic summary for the Western Canada sedimentary basin. Bull. Canad. Petrol. Geol., v. 45, no. 4, pp. 675-692.

Ovtcharova, M., Bucher, H., and Schaltegger, U., 2005, Calibration of the early Triassic biotic recovery: New U/Pb zircon ages from South China (abs): Goldschmidt Conference Abstracts 2005, v. 69/10, supplement 1, p. A324.

Pálfy, J., Parrish, R.R., and Vörös, A., 2003, Mid-Triassic integrated U-Pb geochronology and ammonoid biochronology from the Balaton Highland (Hungary). J. Geol. Soc. London, v. 160, pp. 271-284.

Pálfy, J., Smith, P.L., and Mortensen, J.K., 2000a, A U-Pb and 40Ar/39Ar time scale for the Jurassic, Can. J. Earth Sci., v. 37, pp. 923-944.

Pálfy, J., Mortensen, J.K., Carter, E.S., Smith, P.L., Friedman, R.M., and Tipper, H.W., 2000b, Timing the end-Triassic mass extinction: First on land, then in the sea?, Geology, v. 28, no. 1, pp. 39-42.

Preto, N., Hinnov, L.A., Hardie, L.A., and De Zanche, V., 2001, Middle Triassic orbital signature recorded in the shallow marine Latemar carbonate buildup (Dolomites, Italy). Geology, v. 29, pp. 1123-1126.

Preto, N., Hinnov, L.A., De Zanche, V., Mietto, P., and Hardie, L.A., 2004, The Milankovitch interpretation of the Latemar platform cycles (Dolomites, Italy): Implications for geochronology, biostratigraphy, and Middle Triassic carbonate accumulation. SEPM Spec. Publ. No. 81, pp. 167-182

Preto, N., Spötl, C., Mietto, P., Gianolla, P., Riva, A., and Manfrin, S., 2005, Aragonite dissolution, sedimentation rates and carbon isotopes in deepwater hemipelagites (Livinallongo Formation, Middle Triassic, northern Italy). Sed. Geol., v. 181, pp. 173-194.

Rieber, H., 1973, Cephalopoden aus der Grenzbitumenzone (Mittlere Trias) des Monte San Giorgio (Kanton Tessin, Schweiz). Schweiz. Paläont. Abh., v. 93, pp. 1-96.

Rieber, H., and Brack, P., 2002, The systematic position of Nevadites and (bio)stratigraphic implications. STS/IGCP 467 field meeting, Veszprém, Hungary, 5-8 September, 2002. Geological Institute of Hungary; Abstract volume, pp. 24-25.

Rieber, H., and Brack, P., 2004, Taxonomy and stratigraphic significance of Falsanolcites gen. nov., Anolcites-like Middle Triassic ammonoidea from the Alps and Greece. Mitt. Geol.-Paläont. Inst. Univ. Hamburg, v. 88 , pp. $157-178$

Schatz, W., 2001a, Taxonomic significance of biometric characters and the consequences for classification and biostratigraphy, exemplified through moussoneliform daonellas (Daonella, Bivalvia; Triassic). Paläontolog. Zeitschr., v. 75, no. 1, pp. 51-70.

Schatz, W., 2001b, Revision der Untergattung Daonella (Pichlerella) (Bivalvia, Ladin). Eclogae geol. Helv., v. 94, no. 3, pp. 389-398.

Silberling, N.J., and Nichols, K.M., 1982, Middle Triassic molluscan fossils of biostratigraphic significance from Humboldt range, Northwestern Nevada. Prof. Pap. U.S. geol. Surv., v. 1207, pp. 1-77.

Tozer, T., 1984, The Trias and its ammonoids: The evolution of a time scale. Geol. Surv. Can., Miscellaneous Rep. 35, 171pp.

Tozer, T., 1994a, Canadian Triassic ammonoid faunas. Geol. Surv. Canada Bull., v. 467, pp. 1-663.

Tozer, T., 1994b, Significance of Triassic stage boundaries defined in North America. Mém. de Géologie (Lausanne), v. 22, pp. 155-170.

Vörös, A., 1998, A Balaton-felvidék Triás ammonoideái és biostratigrádiája. Studia Naturalia no. 12, Magyar Természettudományi Múzeum, Budapest, $105 \mathrm{pp}$.

Vörös, A., 2002, Paleoenvironmental distribution of some Middle Triassic ammonoid genera in the Balaton Highland (Hungary). Abh. Geol. B.-A., v. 57 , pp. 479-490.

Vörös, A., Budai, T., Haas, J., Kovács, S., Kozur, H., and Pálfy J., 2003a, GSSP (Global Boundary Stratotype Section and Point) Proposal for the base of the Ladinian (Triassic) A proposal for the GSSP at the base of the Reitzi Zone (sensu stricto) at Bed 105 in the Felsöörs section, Balaton Highland, Hungary. Albertiana, v. 28, pp. 35-47.

Vörös, A., Budai, T., Kovács, S., Piros, O., and Szabó, J., 2003b, Stratigraphy. In: (A. Vörös, ed.) The Pelsonian Substage on the Balaton Highland (Middle Triassic, Hungary). Geologica Hungarica, Series Palaeontologica, Fasciculus 55, pp. 13-43.

Vörös, A., Szabó, J., Kovács, S., Dosztály, L., and Budai, T., 1996, The Felsöörs section: A possible stratotype for the base of the Ladinian Stage. Albertiana, v. 17, pp. 25-40.

Zapfe, H. 1983, Das Forschungsprojekt "Triassic of the Tethys Realm" (IGCP Proj. 4) Abschlussbericht. Schriftenr. erdwiss. Komm. österr. Akad. Wiss., v. 5, pp. 7-16.
Peter Brack is a geologist and curator of the Earth Science collections at the ETH Zurich. After several years as a research and exploration geologist with SHELL Int. He returned to the ETH where he also teaches mineralogy and field geology. The quantification of geological processes is his main research interest, with emphasis on the evolution of Middle Triassic platformbasin systems and magmatism in the Southern Alps as well as on the tectonic framework and emplacement of intrusions around the Tertiary Adamello batholith.

Hans Rieber is a professor em. for palaeozoology and former director of the Palaeontological Institute and Museum of the University of Zurich. Originally focusing on Middle Jurassic ammonoids and stratigraphy since his habilitation he has become a specialist on Triassic invertebrates and stratigraphy. Research on Middle Triassic ammonoids and Daonella started at Monte S. Giorgio (Switzerland; famous for its marine fossils and UNESCO world heritage site) and later extended to sections elsewhere in the Alps, Greece and in Nevada (USA). He has been vice-chair of the Subcommission of Triassic Stratigraphy.

Alda Nicora is a professor of micropaleontology at the Department of Earth Sciences of the University of Milano. She has studied various aspects of stratigraphy and micropaleontology, chiefly concerning conodont and foraminiferal taxonomy and biostratigraphy. She is member of international working groups on conodonts. In recent years, her research efforts are focused on Permian and Triassic conodonts in Northern Italy, Greece, Turkey, Oman, Iran, Himalaya (India and Nepal), Karakorum (Pakistan) and Nevada (USA).
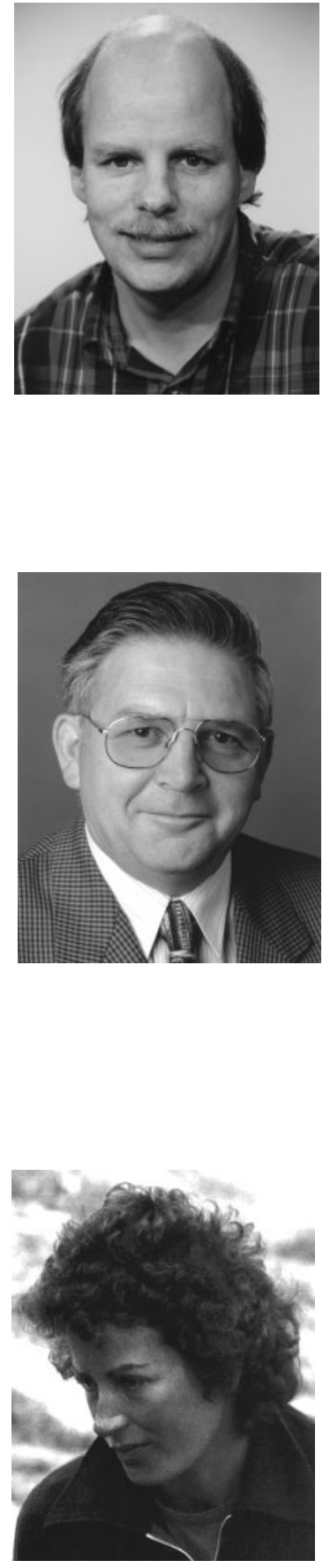

Roland Mundil is at the Berkeley Geochronology Center (California, USA). His research is focused on refining and applying geochronometers. In collaboration with specialists from various fields, he is involved in studying a variety of problems requiring high-resolution age control, such as the timing of mass extinctions and their potential causes, climate change, volcanic processes, continental dynamics (assembly of plutons), etc. 